\title{
PERTANGGUNGJAWABAN PIDANA KORPORASI DALAM TINDAK PIDANA SUMBER DAYA ALAM
}

\author{
Hariman Satria*
}

\author{
Bagian Hukum Pidana, Fakultas Hukum Universitas Muhammadiyah Kendari,Kendari \\ Jalan KH. Ahmad Dahlan No. 10 Kendari Sulawesi Tenggara 93118
}

\begin{abstract}
In ius constitutum of Natural Resources, the liability of corporate criminal, in any case, has been set in five laws. First, fisheries and forestry law have similar formulation that corporations act as makers -undertakers are convicted. Second, plantation law, corporations act as makers -the corporations are convicted. Third, environmental law, corporations as makers -the corporation and the orderer are convicted. Fourth, mineral and coal mining law, corporations as makers -the board and the corporation are convicted. Indeed, there are inconsistencies in the regulation of corporate criminal liability in natural resources sector resulting in legal uncertainty.
\end{abstract}

Keywords: criminal liability, corporate, crime, natural resources.

\section{Intisari}

Dalam ius constitutum SDA, paling tidak pertanggungjawaban pidana korporasi diatur oleh lima undangundang. Pertama UU perikanan dan kehutanan memiliki rumusan yang sama bahwa korporasi sebagai pembuat-pengurus dipidana. Kedua, UU perkebunan, korporasi sebagai pembuat-korporasi dipidana. Ketiga, UU lingkungan hidup, korporasi sebagai pembuat-korporasi dan orang yang memberi perintah dipidana. Keempat, UU minerba, korporasi sebagai pembuat-pengurus dan korporasi yang dipidana. Tegasnya ada inkonsistensi dalam pengaturan pertanggungjawaban pidana korporasi di sektor SDA sehingga menimbulkan ketidakpastian hukum.

Kata kunci: pertanggungjawaban pidana, korporasi, tindak pidana, sumber daya alam.

\section{Pokok Muatan}

A. Latar Belakang Masalah 289

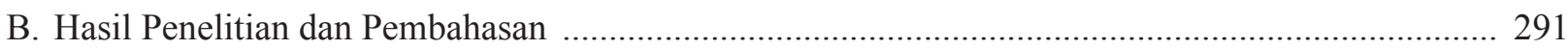

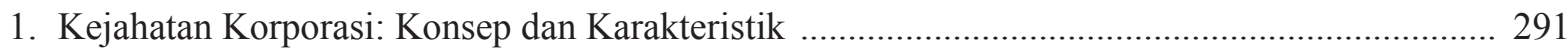

2. Perkembangan Korporasi Sebagai Subyek Delik ..................................................................... 293

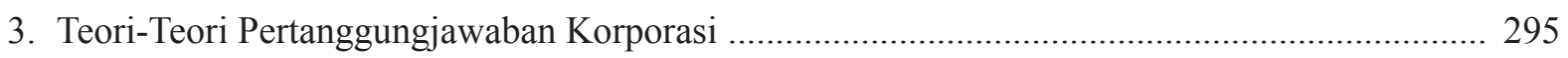

4. Arah Pertanggungjawaban Pidana Korporasi SDA Ke Depan (Ius Constituendum) .................. 297

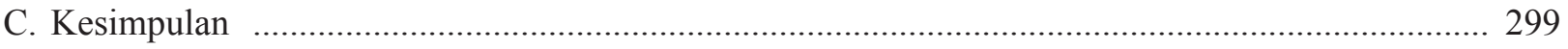




\section{A. Latar Belakang Masalah}

Dalameraglobalisasiterbangunnyakerjasama antara negara diyakini ikut mempengaruhi struktur politik ekonomi internasional, sehingga kadangkala eksistensi suatu negara seolah-olah kedaulatannya berkurang atau mengalami erosi. Secara tegas dikemukakan oleh Nigel Dodd dan Bridget Hutter, "To be synonymous with the erosion of national sovereignty; that is a diminution of the capacity of national goverments to see their economic policies through."1 Meskipun demikian, globalisasi masih diyakini sebagai jalan mendasar untuk melakukan perubahan ekonomi dari negara miskin ke negara maju, termasuk perubahan struktural ekonomi internasional. Kembali ditegaskan oleh Dodd dan Hutter bahwa "That globalization is part of more fundamental, structural change in international political economny, closely associated with-post industrialism."2

Salah satu aktor globalisasi adalah korporasi nasional atau multinasional. Korporasi memegang peranan penting dalam arus perubahan dan pertumbuhan ekonomi dunia. Keberadaan korporasi juga berhubungan dengan penguasaan sumber daya alam dan keuangan global. Kadangkala satu korporasi memonopoli sumber daya lebih banyak dibanding korporasi yang lain. Ini terjadi karena adanya kompetisi antara korporasi sehingga memungkinkan mereka untuk saling mengalahkan dan menguasai. Ketika ada korporasi yang memenangkan kompetisi maka akan dengan mudah mendominasi yang lain. Pada titik ini terjadilah yang disebut dengan kapitalisme global. Suatu kondisi dimana ekonomi dunia hanya dikuasai oleh negara tertentu dengan mengandalkan korporasi nasional atau multinasionalnya. ${ }^{3}$

Mengenai peran korporasi dalam proses terbentuknya kapitalisme ekonomi selanjutnya
diuraikanolehPeterEigan.Eiganmengatakanbahwa, kapitalisme ekonomi diperankan oleh korporasi multinasional atau transnasional corporation atau multinational corporation telah menjalankan operasinya ke seluruh negara berkembang, tetapi mereka tidak tunduk pada negara itu, melainkan tunduk pada hukum negara asalnya atau mahkamah internasional atau mahkamah arbitrase internasional. Karena itu kata Peter dampak dari kapitalisme global akan semakin meluas. Ia berujar bahwa "I worked a long time for the world bank and, at the and of my career. I concluded that all the project I had worked on had been undermined, and even destroyed, by corruption... totally useless project would be created because it was more lurative for some to peasant to repair the existing roads." 4

Jadi kehadiran korporasi ibarat pisau bermata dua. Di satu sisi korporasi berperan penting dalam memacu pertumbuhan ekonomi suatu negara bahkan dunia, tetapi disisi yang lain korporasi menjadi dalang terjadinya kejahatan. Kejahatan yang berkenaan dengan peran korporasi adalah pencemaran lingkungan, pengrusakan hutan, penghancuran populasi perikanan dan perilaku suap atau korupsi serta pencucian uang. ${ }^{5}$ Terkait dengan peran korporasi dalam korupsi kembali disentil oleh Piter, bahwa "The corruption wreaking havoc in these countries is a direct consecuence of the behaviour of multinational companies based in rich industrialized countries that don't hesitate to hand out generous bribery in order to land contracts."

Di Indonesia keberadaan korporasi tersebar di berbagai bidang kehidupan. Ada yang bergerak di sektor pertambangan, kehutanan, perikanan, perkebunan, ada juga di bidang sosial, misalnya sektor pendidikan dan kesehatan. Tidak jarang diantara korporasi tersebut bukan perusahaan Indonesia. Khusus di sektor kehutanan, sejumlah

\footnotetext{
Nigel Dodd dan Bridget Hutter, "Geopolitics and The Regulation of Economic Life", Law and Policy Journal, Vol. 23, No. 2, Januari 1990, hlm. 1 .

Ibid, hlm.2.

David J. Bederman, 2008, Globalization and International Law, Palgrave Macmilan, New York, hlm. 104-105.

Jacques Gelinas, 2003, Juggernaut Politics: Understanding Predatory Globalization, Harvard University Press, New York, hlm. 20-24. Bandingkan dengan Romli Atmasasmita, 2010, Globalisasi dan Kejahatan Bisnis, Kencana Pernada Media Group, Jakarta, hlm. 12.

Muladi dan Dwija Priyatno, 2013, Pertanggungjawaban Pidana Korporasi (Edisi Revisi), Kencana Pernada Media Group, Jakarta, hlm, 2. Jacques Gelinas, Op.cit., hlm. 72.
} 
perusahaan-perusahaan besar yang bergerak cenderung bukanlah perusahaan Indonesia saja. Justru perusahaan induk (holding company) tidak berkedudukan di Indonesia, melainkan di wilayah seperti Singapura atau negara lainnya. Selain itu, hubungan antara holding company dengan perusahaan yang berkegiatan di Indonesia pun seringkali tidak langsung, melainkan dilapisi oleh sejumlah SPV atau dikenal juga dengan shell company yang sengaja dibuat berkedudukan di wilayah secrecy jusrisdiction. ${ }^{7}$

Pendeknya secara ekonomi kehadiran korporasi alias badan usaha tersebut memberi dampak positif kepada negara, namun selain dampak positif, kehadiran korporasi juga dapat menimbulkan dampak negatif. Diantara dampak negatifnya adalah munculnya kejahatan korporasi (corporate crime) seperti pencemaran lingkungan, penambangan illegal, pembakaran hutan, pembunuhan dan penangkapan satwa-satwa liar yang dilindungi. ${ }^{8}$ Kejahatan-kejahatan ini sering pula disebut dengan tindak pidana sumber daya alam. ${ }^{9}$ Kejahatan lain yang dilakukan oleh korporasi adalah mengemplang pajak, penipuan pada kosumen, melakukan penyuapan pada pejabat pemerintah atau petugas pengadilan, dan lain-lain. ${ }^{10}$

Untuk mencegah semakin meluasnya kejahatan korporasi maka sistem hukum nasional sejak tahun 1951 telah memperkenalkan korporasi sebagai subyek delik. ${ }^{11}$ Tidak sampai disitu saja, pada tahun 1955 kembali ditegaskan posisi korporasi sebagai subjek delik dalam tindak pidana ekonomi sehingga dapat dimintai pertanggungjawaban pidana. $^{12}$
Ternyata kehadiran dua undang-undang tersebut, ikut menstimulasi perundang-undangan lain yang juga memposisikan korporasi sebagai subyek delik. Khusus di bidang sumber daya alam, paling tidak korporasi telah diatur pada lima undangundang. Pertama, Undang-Undang Nomor 32 Tahun 2009 tentang Perlindungan dan Pengelolaan Lingkungan Hidup. Kedua, Undang-Undang Nomor 39 Tahun 2014 tentang Perkebunan. Ketiga, Undang-Undang Nomor 4 Tahun 2009 tentang Pertambangan Mineral dan Batubara. Keempat, Undang-Undang Nomor 45 Tahun 2009 tentang Perikanan. Kelima, Undang-Undang Nomor 19 Tahun 2004 tentang Kehutanan.

Jika memperhatikan rumusan norma pada kelima undang-undang tersebut, maka dapat diketahui bahwa ada pengaturan yang berbeda antara undang-undang yang satu dengan undangundang yang lain perihal korporasi sebagai subjek delik dalam tindak pidana sumber daya alam. Dalam Pasal 78 ayat (14) Undang-Undang Nomor 41 Tahun 1999 jo Undang-Undang Nomor 19 Tahun 2004 tentang kehutanan, menyebutkan bahwa apabila tindak pidana dilakukan oleh dan/atau atas nama badan hukum/badan usaha, tuntutan atau sanksi pidananya dijatuhkan kepada pengurusnya. Hal yang sama diatur juga pada Pasal 101 UndangUndang Nomor 45 Tahun 2009 tentang Perikanan, bahwa dalam hal tindak pidana dilakukan oleh korporasi, tuntutan atau sanksi pidananya dijatuhkan kepada pengurusnya. Jadi antara undang-undang kehutanan dan undang-undang perikanan memiliki konsep yang sama dalam merumuskan korporasi sebagai subyek delik.

Secrecy jurisdictions are places that intentionally create regulation for the primary benefit and use of those not resident in their geographical domain. That regulation is designed to undermine the legislation or regulation of another jurisdiction to facilitate its use secrecy jurisdictions also create a deliberate, legally backed veil of secrecy that ensures that those from outside the jurisdiction making use of its regulation cannot be identified to be doing so. Lihat selanjutnya dalam Tax Justice Network, "Financial Secrecy Index", http://www.financialsecrecyindex.com/, diakses 1 Oktober 2015.

Reda Mantovani, "Penuntutan Korporasi dalam Kejahatan Kehutanan", http://www.antikorupsi.org/sites/antikorupsi.org/files/doc/ Reda\%20M_Penuntutan\%20Korporasi\%20dalam\%20Kejahatan\%20Kehutanan.pdf, diakses 1 Oktober 2015.

Lawrence M. Salinger, 2005, Encyclopedia of White Collar Crime Vol 1 \& II, Sage Publication, London, hlm. 211

10 Setiyono, 2005, Kejahatan Korporasi: Analisis Viktimologi dan pertanggungjawaban Korporasi Dalam Hukum Pidana Indonesia, Bayu Media, Malang, hlm. 20

11 Baca Pasal 11 ayat (1) Undang-Undang Darurat No. 17 Tahun 1951 tentang Penimbunan Barang-Barang (Lembaran Negara Nomor 90, Tambahan Lembaran Negara Nomor 155).

12 Baca Pasal 39 ayat (2) Undang-Undang Darurat Nomor 7 Tahun 1955 tentang Pengusutan, Penuntutan dan Peradilan Tindak Pidana Ekonomi (Lembaran Negara Republik Indonesia Tahun 1955 Nomor 27, Tambahan Lembaran Negara Republik Indonesia Nomor 801). 
Pengaturan yang berbeda mengenai posisi korporasi sebagai subyek delik dapat dilihat pada Pasal 113 Undang-Undang Nomor 39 Tahun 2014 tentang Perkebunan. Ditegaskan bahwa apabila tindak pidana dilakukan oleh korporasi maka korporasinya dipidana denda ditambah $1 / 3$. Sementara itu dalam Pasal 116 ayat (1) UndangUndang Nomor 32 Tahun 2009 tentang Lingkungan Hidup, juga memiliki karakter sendiri dalam merumuskan pertanggungjawaban pidana korporasi. Apabila tindak pidana lingkungan hidup dilakukan oleh atau atas nama badan usaha, tuntutan pidana dijatuhkan kepada badan usaha dan/atau orang yang memberi perintah untuk melakukan tindak pidana tersebut. Senada dengan rumusan undang-undang lingkungan hidup, Pasal 163 Undang-Undang Nomor 4 Tahun 2009 tentang Pertambangan Mineral dan Batu Bara, menyebutkan bahwa dalam hal tindak pidana dilakukan oleh badan hukum, selain pidana penjara dan denda pada pengurusnya, pidana juga dijatuhkan kepada badan hukum berupa pidana denda.

Tegasnya dari lima undang-undang di atas, masing-masing memiliki rumusan yang berbeda dalam mengatur korporasi sebagai subjek delik. Pertama dalam undang-undang perikanan dan kehutanan memiliki rumusan yang sama bahwa jika korporasi sebagai pembuat - pengurus yang bertanggung jawab - dipidana. Kedua, undangundang perkebunan memiliki rumusan sendiri, jika korporasi sebagai pembuat - korporasi yang dipidana atau bertanggungjawab. Ketiga, undangundang lingkungan hidup menambahkan hal baru, jika korporasi sebagai pembuat - korporasi dan orang yang memberi perintah yang dipidana. Keempat, undang-undang minerba memuat rumusan yang lebih sederhana, korporasi sebagai pembuat - pengurus dan korporasi yang dipidana.

Jadi jika memperhatikan rumusan undangundang tersebut di atas, maka dapat diketahui bahwa antara undang-undang tidak memiliki konsep yang sama dalam menempatkan korporasi sebagai subjek delik ada ketidakkonsistenan. Hal ini akan berimbas dalam penerapannya oleh aparat penegak hukum, sebab dapat menimbulkan ketidakpastian hukum. Untuk itu perlu dilakukan reformulasi pengaturan pertanggungjawaban pidana korporasi melalui penal policy. Atas dasar inilah sehingga penulis membuat kajian tentang, pertanggungjawaban pidana korporasi dalam tindak pidana sumber daya Alam". Agar sistematis, tulisan ini penulis bagi dalam beberapa bagian, masing-masing adalah kejahatan korporasi: konsep dan karakteristik, perkembangan korporasi sebagai subjek delik, teoriteori pertanggungjawaban pidana korporasi, arah pertanggungjawaban pidana korporasi di sektor SDA di masa yang akan datang (ius constituendum).

\section{B. Hasil Penelitian dan Pembahasan \\ 1. Kejahatan Korporasi: Konsep dan Karak- teristik}

Meskipun tidak selalu ada pertanggungjawaban pidana jika terjadi perbuatan pidana tetapi ketika berbicara tentang perbuatan pidana dan pertanggungjawaban pidana, kedua variabel ini tidak dapat dipisahkan satu sama lain. Demikian pula jika membahas tentang pertanggungjawaban pidana korporasi adalah tidak dapat dipisahkan dari kejahatan korporasi. Idealnya sebelum mengulas pertanggungjawaban pidana korporasi maka terlebih dahulu akan diulas tentang kejahatan korporasi. Sebab adanya pertanggungjawaban pidana korporasi dikarenakan adanya kejahatan korporasi itu sendiri.

Secara harfiah korporasi berasal dari bahasa latin, corporatio. Kata ini berasal dari bahasa latin yang lebih tua yakni corporare. Corporare sendiri berasal dari kata corpus yang berarti memberikan badan atau membadankan. ${ }^{13}$ Dari kata corporatio tersebut diterjemahkan ke dalam berbagai bahasa di Eropa, seperti corporatie (Belanda), corporation (Inggris), corporation (Jerman). Dari kata corporatie

13 Jon R. Stone, 2005, Dictionary of Latin Quotations: The Illiterati’s Guide to Latin Maxims, Mottoes, Proverbs, and Sayings, Routledge Taylor and Francis Group, New York, hlm. 17. 
(Belanda) tersebut akhirnya diterjemahkan ke dalam bahasa Indonesia menjadi korporasi.

Satjipto Rahardjo mengatakan, bahwa korporasi sebagai suatu badan hasil ciptaan hukum. Badan hukum yang diciptakannya itu terdiri dari "corpus" yaitu struktur fisiknya - mengarah pada fisiknya dan "animus" yang diberikan hukum membuat badan hukum itu mempunyai kepribadian. Oleh karena badan hukum itu merupakan ciptaan hukum, kecuali penciptaannya - kematiannya pun ditentukan oleh hukum. ${ }^{14}$ Berkenaan dengan itu, Briyan A. Garner mengartikan korporasi sebagai "An entity (ussualy a business) having authority under law to act as a single person distinct from the shareholders who own it and having right to issues stock and exist indifinitely, a group or succsession of person estabilished in accordance with legal rules into or juristic that has legal personality distinct from the natural persons who make it up, exist indefinitely a part from them, and has the legal powers that it constitution give it." 15

Secara sederhana dapat dikatakan bahwa definisi ini kelihatannya melihat korporasi dalam konteks bisnis - perdata. Tetapi pertanyaannya adalah dari aspek hukum pidana apakah korporasi itu? Jika merujuk pada Pasal 51 ayat (3) Wetboek van Strafrecht Belanda, dipersamakan dengan korporasi adalah persekutuan bukan badan hukum (termasuk comanditaire venootschap/perseroan komanditer, vennootschap onder firma/persekutuan firma, maatschap/persekutuan perdata, rederij/perusahaan perkapalan dan doelvermogen/yayasan. ${ }^{16}$

Loncatan pemikiran tentang korporasi termasuk kedudukannya sebagai subjek hukum subyek delik, dalam hukum pidana dikemukakan oleh Eddy O.S Hiariej. Menurutnya, pada awalnya pembuat undang-undang berpandangan bahwa hanya manusia saja yang dapat menjadi subjek hukum tindak pidana. Hal ini dapat dilihat dari sejarah perumusan Pasal 59 KUHP, terutama dari cara bagaimana delik dirumuskan dengan adanya frasa "hij die" yang berarti barangsiapa. Dalam perkembangannya, pembuat undang-undang ketika merumuskan delik turut memperhitungkan kenyataan bahwa manusia juga terkadang melakukan tindakan di dalam atau melalui organisasi dalam hukum keperdataan, sehingga muncul pengaturan terhadap badan hukum atau korporasi sebagai subjek hukum dalam hukum pidana. ${ }^{17}$

Sementara itu Sally S. Simpson, melihat kejahatan korporasi sebagai bagian dari kejahatan kerah putih. Ditegaskan oleh Simpson, corporate crime is type of white collar crime. ${ }^{18}$ Pandangan ini tidak memberi definisi tentang kejahatan korporasi tetapi menjadi bagian penting dalam membahas kejahatan yang dilakukan oleh korporasi. Bahwa kejahatan korporasi dapat terjadi secara simultan dengan kejahatan kerah putih. Dalam kosa kata lain, ketika terjadi kejahatan kerah putih maka mutatis mutandis terselip adanya kejahatan korporasi.

Istilah white collar crime itu sendiri, tidak dapat dipisahkan dari seorang kriminolog yang bernama Edwin H. Sutherland. Pada tahun 1939 dihadapan American Sociological Society, Sutherland berpidato dan memperkenalkan istilah white collar crime. Term ini ditujukan untuk menggambarkan aktifitas kejahatan yang dilakukan oleh seseorang, memiliki status sosial yang tinggi dan dihormati. Seseorang tersebut menggunakan jabatannya untuk melakukan sesuatu yang melanggar hukum. Secara gamblang diulas oleh Simpson, "The concept of white collar crime are to describe criminal activity by persons of high social status and respectability who use their occupational position as a means violate the law." 19 Selain itu pula penggunaan term white collar crime sekaligus

\footnotetext{
14 Satjipto Rahardjo, 2006, Ilmu Hukum (Edisi Revisi), Alumni, Bandung, hlm. 110.

15 Bryan A. Garner, 2011, Black's Law Dictionary (Seventh Edition), St. Paul Minn West Publishing, New York, hlm. 341. Lihat juga Henry Campbell Black, 1968, Black's Law Dictionary: Definition of The Term and Phrases of American and English Jurisprudence, Ancient and Modern (Revisied Edition), ST Paul Minn West Publishing, New York, hlm. 409.

16 Jan Remelink, 2003, Hukum Pidana: Komentar Atas Pasal-Pasal Terpenting Dalam Kitab Undang-Undang Hukum Pidana Belanda dan Padanannya Dalam Kitab Undang-Undang Hukum Pidana Indonesia, Gramedia Pustaka Utama, Jakarta, hlm. 99.

17 Eddy O.S Hiariej, 2014, Prinsip-Prinsip Hukum Pidana, Cahya Atma Pustaka, Yogyakarta, hlm. 156-157.

18 Sally S. Simpson, 2005, Corporate Crime, Law, and Social Control, Cambridge University Press, New York, hlm. 6.

19 Ibid
} 
menjadi pembeda dari kejahatan biasa (street crimes) seperti perampokan, pembunuhan atau penyerangan yang selama ini cukup familiar dalam lingkungan sosial. Untuk itu dalam pidatonya Sutherland menyentil para ekonom dan sosiolog Amerika Serikat kala itu yang menurutnya telah kehilangan sesuatu karena tidak bekerjasama satu sama lain dalam menganalisis kejahatan. ${ }^{20}$

Kembali pada kejahatan korporasi, John Braithwaite menguraikan secara sederhana definisi kejahatan korporasi. Braithwaite mengatakan "Corporate crime is the conduct of a corporation, or of employees acting on behalf of a corporation, which is prescribed and punishible by law."21 Definisi lebih luas tetapi hampir sama, perihal kejahatan korporasi dikemukakan oleh Marshall B. Clinard dan Peter C. Yeagar, "That a corporate crime is any act commited by corporation that is punished by the state, regaardless of whether it is punished under administrative, civil or criminal law."22 Jadi dikatakan sebagai kejahatan korporasi manakala perbuatan itu dilakukan oleh korporasi yang dapat dihukum oleh negara baik melalui hukum administrasi, hukum perdata atau hukum pidana.

Selain itu perlu diketahui pula, bahwa ketika berbicara mengenai kejahatan korporasi paling tidak ada tiga gradasi hukum. Pertama, crimes for corporation. Kedua, crimes against corporation. Ketiga, criminal corportions. Pada dasarnya crimes for corporation inilah yang disebut sebagai kejahatan korporasi. Dalam hal ini dapat dikatakan corporate crime are clearly commited for the corporate, and not against. Kejahatan korporasi dilakukan untuk kepentingan korporasi bukan sebaliknya. Sementara itu crimes against corporation adalah kejahatan yang dilakukan oleh pengurus korporasi itu sendiri (employes crime). Dalam hal ini korporasi sebagai korban dan pengurus sebagai pelaku. Sedangkan criminal corporation adalah korporasi yang sengaja dibentuk untuk melakukan kejahatan. Kosa kata lainnya adalah korporasi hanya dijadikan sebagai "topeng" untuk memuluskan penyembunyian wajah asli korporasi sebagai pelaku kejahatan. ${ }^{23}$

Dengan demikian, jika berbicara tentang kejahatan korporasi tidak terpisah dengan kejahatan kerah putih (white collar crime). Kejahatan korporasi dilakukan oleh mereka yang memiliki posisi penting dalam suatu korporasi. Demikian halnya dengan kejahatan kerah putih yang juga dilakukan oleh orang-orang yang memiliki kedudukan, jabatan atau posisi yang patut dihormati. Karena itu seperti yang telah diulas di atas bahwa ketika terjadi kejahatan korporasi maka mutatis mutandis terjadi juga kejahatan kerah putih, demikian sebaliknya

\section{Perkembangan Korporasi Sebagai Subyek Delik}

Pengakuan korporasi sebagai subyek delik, tidak semulus pengakuan pada manusia. Banyak rintangan dan tantangan secara teoritis atas ide atau gagasan bahwa korporasi dapat menjadi subjek delik. Paling tidak ada dua probable cause sampai kondisi ini terjadi. Pertama, sebagaimana diketahui bahwa, teori fiksi begitu kuat pengaruhnya dalam jagat ilmu hukum termasuk hukum pidana. Von Savigny adalah orang yang bertanggungjawab atas teori ini. Bahwa kepribadian hukum sebagai satu kesatuan dengan manusia hanya khayalan saja. Kepribadian yang sebenarnya hanya ada pada manusia. Memperhatikan teori ini tentu akan mempesulit korporasi sebagai subjek delik karena secara nyata korporasi tidak memiliki kalbu atau kepribadian sebagaimana halnya manusia, sehingga sulit untuk mencari kesalahannya.

Kedua, masih dominannya penganut asas universitas delinquere non potest (korporasi tak dapat dipidana) dan asas societas delinquere non potest (korporasi tidak mungkin melakukan

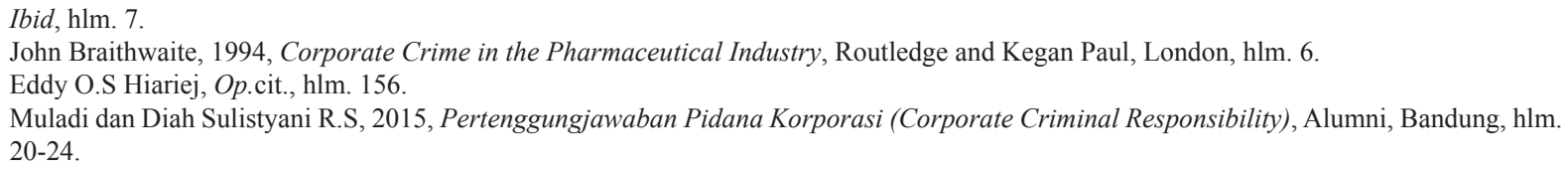


perbuatan pidana) dalam hukum pidana. Kedua asas ini tidak hanya menghambat pengakuan korporasi sebagai subyek delik tetapi lebih dari itu, asas ini telah merintangi negara dalam menuntut tanggung jawab korporasi atas tindakannya yang melanggar hukum dan merugikan masyarakat. Dalam perkembangannya dua alasan di atas lama kelamaan semakin memudar pengaruhnya. Hal ini dapat dikonfirmasi dengan melihat adanya usaha untuk menjadi korporasi sebagai subyek hukum dalam hukum pidana - subyek delik. Usaha tersebut didasari oleh fakta, bahwa tidak jarang korporasi mendapat keuntungan dari hasil kejahatan yang dilakukan oleh pengurusnya. Demikian halnya kerugian yang diderita masyarakat akibat perbuatan yang dilakukan oleh pengurus korporasi. ${ }^{24}$

Menurut D. Schafmeister, N. Keijzer dan E.P.H. Sutorius, bahwa penerimaan korporasi sebagai subjek hukum terbagi dalam tiga tahap. Pertama, yaitu sejak KUHP dibentuk Tahun 1886, pembentuk undang-undang telah mulai memasukkan beberapa peraturan berupa perintah dan larangan terhadap pengurus agar bertanggungjawab dalam pelaksanaan peraturan tersebut dalam badan atau perusahaan yang dipimpinnya. Pada tahap ini, masih sebatas usaha-usaha agar perbuatan pidana yang dilakukan oleh badan hukum, hanya dipertanggungjawabkan kepada perorangannya saja.

Kedua, pasca Perang Dunia I, dalam perumusan undang-undang telah ditentukan bahwa perbuatan pidana itu dapat dilakukan oleh korporasi namun pertanggungjawabannya masih tetap ada pada pengurus atau anggota, pimpinan dari korporasi tersebut. Pada tahap ini sudah mulai ada peralihan tanggung jawab dari anggota pengurus, kepada mereka yang memerintahkan atau secara nyata memimpin badan hukum dalam melakukan perbuatan pidana tersebut. Ketiga, pada saat dan sesudah Perang Dunia II, tanggung jawab pidana langsung dari korporasi juga turut dianut. Korporasi secara kumulatif dipertanggungjawabkan menurut hukum pidana, disamping mereka yang memberi perintah atau memimpin secara nyata telah berperan dalam perbuatan pidana tersebut. ${ }^{25}$

Di Belanda secara tegas menerima korporasi sebagai subyek delik sejak 1 September 1976 yang ditetapkan dalam hukum pidana umum (commune strafrecht) dan juga telah menentukan siapa yang harus bertanggungjawab maupun turut bertanggungjawab atas tindak pidana yang dilakukan oleh korporasi. Dalam Pasal 51 Wetboek van Strafrech Belanda menyebutkan, bahwa (1) perbuatan pidana dapat dilakukan oleh perorangan dan oleh badan hukum. (2) apabila tindak pidana dilakukan oleh badan hukum, maka penuntutan pidana jika dianggap perlu dapat dijatuhkan pidana dan tindakan yang tercantum dalam undang-undang terhadap: 1) badan hukum; atau 2) terhadap mereka yang memerintahkan melakukan perbuatan itu, demikian pula terhadap mereka yang bertindak sebagai pimpinan melakukan tindakan yang dilarang itu; atau 3) terhadap 1 dan 2 melakukan perbuatan terlarang itu secara bersama-sama. ${ }^{26}$

Sementara itu di Indonesia sejak tahun 1951, dapat dikatakan telah menerima korporasi sebagai salah satu subyek delik, yang dapat pula dimintai pertanggungjawaban pidana. $^{27}$ Bahkan dalam Undang-Undang Darurat No. 7 Tahun 1955 tentang Pengusutan, Penututan dan Peradilan Tindak Pidana Ekonomi, ikut mengintegrasikan korporasi sebagai subyek hukum - subyek delik. ${ }^{28}$ Namun sejak saat itu hingga Tahun 2010 hanya dua korporasi yang dijadikan tersangka dan terdakwa oleh Kejaksaan

\footnotetext{
Neal Shover dan Andy Hochstetler, 2006, Choosing White Collar Crime, Cambridge University Press, New York - Melbourne, hlm. 5-6.

24 D. Schaffmeister, et al., 1995, Hukum Pidana (terj. J.E Sahetapy), Liberty, Yogyakarta, hlm. 274-276.

26 Pasal 51 Wetboek van Strafrecht: (1) strafbare feiten kunen worden begaan door naturalijke personen en rechtpersonen. (2) Indien een strafbaar feit wordt begaan door een rechtpersoon, kan de strafvervolging worden ingesteld en kunnen de in de wet voorziane straffen en maatregelen, indien zij daarvoor in aanmerking komen, worden uitgesporken: 1) tegen die rechtperson, dan wel 2) tegen hen die tot het feit opdracht hebben gegeven, elsmede tegen hen die feitelijke leiding hebben gegeven aan de verboden gedraging, dan wel 3) tegen de onder 1 en 2 genoemden te zamen.

27 Eddy O.S Hiariej, Loc.cit.

28 Baca Pasal 15 ayat 1-4 Undang-Undang Darurat Nomor 7 Tahun 1955 tentang Pengusutan, Penuntutan dan Peradilan Tindak Pidana Ekonomi (Lembaran Negara Republik Indonesia Tahun 1955 Nomor 27, Tambahan Lembaran Negara Republik Indonesia Nomor 801).
} 
Agung yaitu PT Newmont Minahasa Raya di Manado (Putusan No. 284/Pid.B/2005/PN. Mdo) ${ }^{29}$ dan PT Giri Jaladi Wana di Banjarmasin (Putusan No. No. 812/Pid.Sus/2010/PN.BJM). Ini penting menjadi catatan, karena dapat dikatakan bahwa progres aparat penegak hukum dalam penetapan korporasi sebgai tersangka/terdakwa masih lamban.

3. Teori-Teori Pertanggungjawaban Korporasi

Berbicara tentang pertanggungjawaban, menarik dicermati kata-kata yang pernah diungkapkan oleh Roscoe Pound bahwa "That I shall use the simple word "liability" for the situation whereby one may exact legally and the other is legally subjected to the exaction." ${ }^{30}$ Pesan filosofis yang hendak disampaikan oleh Pound adalah bahwa di dalam pertanggungjawaban atau liability terkandung makna suatu kewajiban untuk membayar "pembalasan" yang akan diterima pelaku dari seseorang yang telah "dirugikan".

Merujuk pada penjelasan Pound tersebut, maka Romli Atmasasmita mengatakan bahwa, jika pembalasan sebagai suatu alat pangkal, maka pembayaran ganti rugi bergeser kedudukannya, semula sebagai suatu "hak istimewa" kemudian menjadi suatu "kewajiban". Ukuran ganti rugi tersebut tidak lagi dilihat dari nilai suatu pembalasan yang harus dibeli melainkan dari sudut kerugian atau penderitaan yang ditimbulkan oleh perbuatan pelaku yang bersangkutan. Oleh karena itu konsep liablity diartikan sebagai reparation sehingga terjadilah perubahan arti konsepsi liability dari compotition for vengeance menjadi reparation for injury. Perubahan wujud ganti rugi, semula dengan "sejumlah uang" kemudian diubah dengan "penjatuhan hukum". Secara historis teori ini menjadi awal mula dari liability. ${ }^{31}$

Sementara itu, prinsip bahwa korporasi dapat dipertanggungjawabkan dari kejahatan yang dilakukan oleh pengurusnya, tidak dapat dilepaskan dari kemunculan pengadilan gereja di abad pertengahan. Kala itu gereja menanggapi dugaan ajaran sesat dalam tubuh perusahaan, terutama biara dengan mengucilkan mereka. Ditegaskan oleh Lawrence M. Salinger, bahwa, "The principle that a corporation can be accountable for the crimes of it's agents arose in church courts in mediavel times. The church responded to alleged heresy in corporate bodies, most notably monasteries, by excommunicating them." ${ }^{32}$ Dari pengadilan gereja tersebut, dapat dipahami bahwa secara perlahan korporasi sudah mulai diakui sebagai entitas yang dapat dipertanggungjawabkan secara hukum.

Mengenai pertanggungjawaban pidana korporasi, dapat ditemukan tiga model pertanggungjawaban. ${ }^{33}$ Pertama, pengurus korporasi sebagai pembuat dan penguruslah yang bertanggungjawab. Gagasan ini dilandasi oleh pemikiran bahwa badan hukum tidak dapat dipertanggungjawabkan secara pidana, karena penguruslah yang akan selalu dianggap sebagai pelaku dari delik tersebut. Kedua, korporasi sebagai pembuat dan pengurus yang bertanggung jawab. Jadi model ini menyadari bahwa korporasi sebagai pembuat namun untuk pertanggungjawabannya diserahkan kepada pengurus. Ketiga, korporasi sebagai pembuat dan juga sebagai yang bertanggungjawab. Model ini memperhatikan perkembangan korporasi itu sendiri, karena ternyata hanya dengan menetapkan pengurus sebagai yang bertanggung jawab, tidaklah cukup. $^{34}$

Masih mengenai pertanggungjawaban pidana korporasi, pada dasarnya ada lima teori yang berhubungan dengan itu. Pertama, teori identifikasi, biasa disebut dengan direct corporate criminal liablity atau pertanggungjawaban pidana korporasi

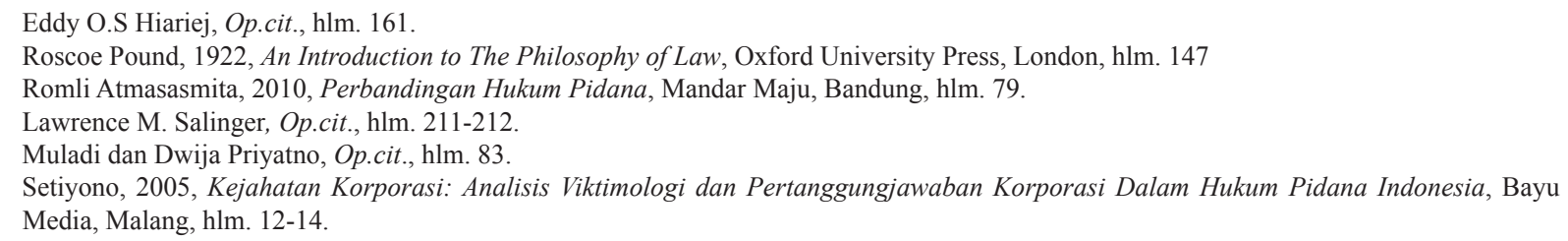


secara langsung. ${ }^{35}$ Menurut teori ini korporasi bisa melakukan sejumlah delik secara langsung melalui pengurus yang sangat berhubungan erat dengan korporasi, bertindak untuk dan atas nama korporasi sehingga dipandang sebagai perusahaan itu sendiri. ${ }^{36}$ Mereka tidak sebagai pengganti dan oleh karena itu, pertanggungjawaban korporasi tidak bersifat pertanggungjawaban pribadi. ${ }^{37}$

Kedua, strict liability. Menurut Paul Dobson, dinyatakan bahwa "These are some crimes for which with regard to at least one element of the actus reus, no mens rea is required." ${ }^{38}$ Karena itu strict liability diartikan sebagai pertanggungjawaban yang ketat menurut undang-undang. Jadi pertanggungjawaban korporasi semata-mata berdasarkan bunyi undangundang dengan tanpa memandang siapa yang melakukan kesalahan. Dalam strict liability unsur kesalahan tidak perlu dibuktikan. Ada dua tujuan utama memaksakan strict liability. Pertama, to protect the public from dangerous actions by creating a higher standard of care. Kedua, to regulate quasi-criminal activities in as efficient manner posible. ${ }^{39}$

Ketiga, vicarious liability. Doktrin pertanggungjawaban pengganti, yang lebih menekankan pada pertanggungjawaban pengurus korporasi sebagai agen perbuatan dari korporasi tersebut. Ditegaskan oleh Paul Dobson, "A corporation is vicariously liable for the acts of its employees or agents in normal situations of vicarious liability." ${ }^{\prime 40}$ Ajaran ini bertolak dari doktrin respondent superior, berdasarkan pada employment principle dan the delegation principle. Doktrin ini adalah pengecualian pertanggungjawaban individu yang dianut dalam hukum pidana berdasarkan adugium nemo punitur pro alieno delicto (tidak ada seorang pun yang dihukum karena perbuatan orang lain). ${ }^{41}$
Dengan demikian ketika berbicara vicarious liability di dalamnya memuat sebuah prinsip pertanggungjawaban pengganti atas perbuatan pidana yang dilakukan oleh orang lain.

Keempat, teori agregasi yang menyatakan bahwa pertanggungjawaban pidana dapat dibebankan kepada badan hukum jika perbuatan tersebut dilakukan oleh sejumlah orang yang memenuhi unsur delik yang mana antara satu dengan yang lain saling terakit dan bukan berdiri sendiri-sendiri.

Kelima, doktrin corporate cultural model atau model budaya kerja. Ajaran ini memfokuskan pada kebijakan badan hukum yang tersurat dan tersirat mempengaruhi cara kerja badan hukum tersebut. Badan hukum dapat dipertanggungjawabkan secara pidana apabila tindakan seseorang memiliki dasar yang rasional bahwa badan hukum tersebut memberikan wewenang atau mengizinkan perbuatan tersebut dilakukan. ${ }^{42}$

Selain teori-teori tersebut, Sutan Remy Sjahhdeini memperkenalkan teori lain yang disebut dengan ajaran gabungan yaitu gabungan ajaran identifikasi, ajaran intra vires, ajaran keterkaitan fungsi, ajaran manfaat, ajaran legal entity dan ajaran agregasi. Menurut teori ini, untuk mempertanggungjawabkan korporasi sebagai subyek delik, maka harus terpenuhi enam unsur penting. Pertama, tindak pidana harus dilakukan oleh directing mind (personil pengendali) korporasi, baik dilakukan sendiri atau diperintahkan olehnya untuk dilakukan oleh orang lain (doctrine of identification). Kedua, tindak pidana tersebut dilakukan dalam rangka maksud dan tujuan korporasi (intra vires). Ketiga, tindak pidana dilakukan oleh pelaku atau atas perintah pemberi perintah dalam rangka tugasnya dalam korporasi. Keempat, tindak pidana tersebut

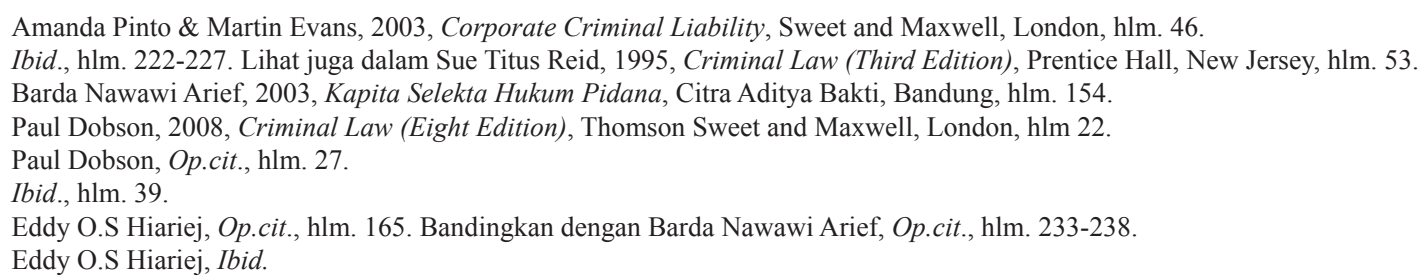


dilakukan untuk memberikan manfaat bagi korporasi. Kelima, pelaku atau pemberi perintah tidak memiliki alasan alasan pembenar atau alasan pemaaf untuk dibebaskan dari pertanggungjawaban pidana. Keenam, actus reus dan mens rea tidak harus berada pada satu orang tetapi mens rea harus ada pada directing mind (personil penggendali) korporasi, sedangkan actus reus-nya dapat dilakukan oleh satu atau beberapa orang lain (doctrine of aggregation). ${ }^{43}$

\section{Arah Pertanggungjawaban Pidana Korpo-} rasi SDA ke Depan (Ius Constituendum)

Di atas telah diulas perihal inkonsistensi sejumlah undang-undang di sektor sumber daya alam, ketika mengatur mengenai pertanggungjawaban pidana korporasi. Karena itu pada bagian ini akan diuraikan konsep ideal perihal pertanggungjawaban pidana korporasi di sektor sumber daya alam pada masa yang akan datang (ius constituendum). Dengan kata lain kita akan berbicara tentang kebijakan pidana atau kebijakan kriminal khusus menyangkut pertanggungjawaban pidana korporasi sebagai subyek delik. Marc Ancel, mengatakan bahwa "Criminal policy is the rational organization of the control of crime by society." Bahwa yang dikatakan sebagai kebijakan kriminal adalah bagian dari usaha rasional masyarakat dalam menanggulangi kejahatan.

Seturut dengan itu, kebijakan kriminal sering pula disebut sebagai criminal policy yang tujuan akhirnya adalah perlindungan masyarakat (social defence) dan kesejahteraan masyarakat (social welfare).$^{45}$ Hal ini diamini dalam laporan UNAFEI di Tokyo 1974, "That most of groups members agreed some discussion that protection of the society could be accepted as the final good of criminal policy, although not the ultimate aim of society, which might perhaps be described by terms like happiness of citizens a wholesome and cultural living social welfare or equality". ${ }^{46}$ Intinya jika membahas tentang penal policy maka tercakup tiga hal yakni kebijakan formulasi, kebijakan aplikasi dan kebijakan eksekusi. ${ }^{47}$

Penal policy dalam konteks pertanggungjawaban pidana korporasi di sektor SDA adalah lebih condong pada upaya melakukan pembaharuan hukum pidana (perundang-undangan pidana) yang fokus utamanya adalah melakukan perbaikan terhadap sistem pertanggungjawaban pidana korporasi. Perbaikan tersebut dimulai pada tahap formulasi, aplikasi hingga tahap eksekusi. Adapun tujuan akhirnya adalah untuk kepentingan perlindungan sosial (social defence) dan kesejahteraan masyarakat (social welfare).

Masih mengenai penal policy, substansinya adalah upaya untuk mereformulasi peraturan pidana dalam hukum positif yang dirumuskan secara lebih baik untuk memberi pedoman (guidelines) tidak hanya pada pembentuk undang-undang (kebijakan fornulasi) tetapi juga oleh pengadilan (kebijakan aplikasi) yang akan menerapkan undang-undang tersebut. Lebih jauh lagi undang-undang yang telah doformulasikan itu akan digunakan (kebijakan eksekusi) oleh penyelenggara negara atau pelaksana putusan pengadilan. Sebisa mungkin tiga hal tersebut berjalan beriringan sehingga dapat memberikan kepastian hukum dan bermanfaat bagi masyarakat.

Merujuk pada uraian penal policy di atas, maka dalam konteks pertanggungjawaban pidana korporasi di sektor SDA akan diarahkan pada upaya mereformulasi ketentuan tentang pertanggungjawaban pidana korporasi sehingga pada ujungnya dapat memberi kepastian hukum. Selain itu pula mampu mengakomodasi tujuan pemidanaan yang tidak sekedar menjatuhkan sanksi pidana tetapi juga memberikan efek jera (deterence effect) agar pelaku kejahatan tidak mengulangi

43 Sutan Remy Sjadeini, 2006, Pertanggungjawaban Pidana Korporasi, Grafiti Pers, Jakarta, hlm. 118.

44 Marc Ancel, 1965, Social Defence, A Modern Approach to Criminal Problems, Routledge \& Kegan Paul, London, hlm. 209.

45 Barda Nawawi Arief, 2008, Bunga Rampai Kebijakan Hukum Pidana: Perkembangan Penyusunan RUU KUHP Baru, Kencana Pernada Media Group, Jakarta, hlm. 2.

46 Summary Report, Resource Material Series No. 07, UNAFEI, 1974, hlm. 95.

47 Barda Nawawi Arief, Op.cit., hlm. 213. 
kembali kejahatannya, mampu merehabilitasi mental pelaku kejahatan sebab pidana dimaknai sebagai obat (poenae ut medicine) serta pidana juga diharapakan dapat memulihkan keadilan (restorative justice) ${ }^{48}$

Oleh karena itu dalam tulisan ini, penal policy atau pembaharuan hukum pidana akan difokuskan pada tiga bagian penting. Pertama, keseragaman bentuk pertanggungjawaban pidana korporasi di sektor SDA. Kedua, konsistensi pada konsep double track system. Ketiga, perihal penguatan pada strafsoort dan strafmaat yang lebih strictly.

Pertama, jika pertanggungjawaban pidana korporasi diatur secara tidak seragam maka hal itu berpotensi menimbulkan ketidakpastian hukum disebabkan oleh peraturan yang tidak jelas. Dengan kata lain melanggar prinsip nullum crimen noela poena sine lege certa atau lex certa - lex certa. ${ }^{49}$ Padahal setiap penegakan hukum tujuannya adalah memberi kepastian hukum sebagai pedoman bagi aparat hukum dan masyarakat, sehingga dapat memberi manfaat dalam pelaksanaannya - pada akhirnya subjek hukum merasa diperlakukan secara adil oleh hukum itu sendiri. ${ }^{50}$

Idealnya pembentuk undang-undang merumuskan sebuah formula yang tegas dan jelas mengenai bentuk pertanggungjawaban pidana korporasi di sektor SDA. Berdasarkan teori-teori pertanggungjawaban pidana korporasi maka teori ideal untuk menuntut koporasi adalah memadukan teori strict liablity dan direct corporate criminal liability.Perpaduankeduateoriiniakanmemudahkan aparat penegak hukum dalam menuntut dan membuktikan kesalahan korporasi. Jika pengurus korporasi/karyawan melakukan kejahatan yang terkait dengan korporasi maka mutatis mutandis korporasi ikut bertanggungjawab. Penuntutan terhadap korporasi tidak menghilangkan tanggung jawab pidana pengurus/karyawan tersebut.

Kedua, patut pula menjadi perhatian adalah perihal kemungkinan penggunaan konsep double track system, ${ }^{5 l}$ dalam undang-undang di sektor SDA. Pembentuk undang-undang seharusnya mengintegrasikan ketentuan sanksi pidana dan tindakan secara bersamaan..$^{52}$ Apalagi sebelumnya dalam sistem hukum nasional telah ada undangundang tindak pidana ekonomi yang mengadopsi konsep double track system dalam permusan sanksi pidana. Sanksi pidana penjara diharapkan memberikan efek jera kepada pelaku sedangkan sanksi tindakan ditujukan untuk memberikan perlindungan kepada kepentingan masyarakat dengan harapan si pelaku dapat berubah atau bertobat atas kejahatan yang telah dilakukannya. Hal ini diuraikan pula oleh Jonkers, bahwa sanksi pidana yang diterapkan untuk kejahatan yang dilakukan, sedangkan sanksi tindakan mempunyai tujuan yang bersifat sosial. ${ }^{53}$ Sanksi pidana dan tindakan ini akan leboh efektif digunakan untuk menghukum korporasi dan pengurusnya.

Ketiga, kebijakan formulasi yang lain adalah mengenai strafmaat yang seharusnya menggunakan pola indeterminate of sentencing. Perumusan sanksi pidana yang bersifat minimum khusus dan maksimum khusus. Ancaman pidana bagi pengurus korporasi yang melakukan kejahatan berhubungan dengan korporasi dapat dirumuskan ancaman pidana penjara minimal 1 tahun dan maksimal 20 tahun. Demikian pula pidana denda sebaiknya bersifat minimum khusus atau indeterminate of sentencing dipadukan dengan pola yang dirumuskan dalam RUU KUHP saat ini yang menggunakan model denda kategori I-IV. Selanjutnya mengenai formulasi strafsoort akan lebih baik jika mengakomodasi sistem yang bersifat tunggal, alternatif dan kumulatif. Artinya jenis sanksi pidana

\footnotetext{
Wayne R. Lavave, 2010, Principle of Criminal Law, West A Thomson Reuters Bussines, London, hlm. 25-26.

49 Matcheld Boot, 2001, Nullum Crimen Sine Lege and The Subject Matter Jurisdiction of the International Criminal Court: Genocide, Crimes Against Humanity, War Crimes, Intersentia Antwerpen, New York, hlm. 94.

Sudikno Mertokusumo dan A. Pitlo, 2013, Bab-Bab Tentang Penemuan Hukum, Citra Aditya Bakti, Bandung, hlm. 1-2.

51 M. Sholehuddin, 2007, Sistem Sanksi Dalam Hukum Pidana: Ide Dasar Double Track System \& Impelementasinya, Rajawali Press, Jakarta, hlm. 23 .

52 Hariman Satria, 2014, Anatomi Hukum Pidana Khusus, UII Press, Yogyakarta, hlm. 159.

53 J.E Jonkers, 1987, Buku Pedoman Hukum Pidana Hindia Belanda, Bina Aksara, Jakarta, hlm. 350.
} 
dalam pertanggungajawaban pidana di sektor SDA memungkinkan sanksi tunggal (hanya penjara, denda) tetapi bisa juga sanksi alternatif (penjara atau denda) atau bahkan kumulatif (penjara dan denda).

\section{Kesimpulan}

Berdasarkan uraian tersebut di atas, maka ada beberapa hal yang penting ditegaskan melalui tulisan ini. Pertama, berbicara tentang kejahatan korporasi mutatis mutandis di dalamnya terjadi pula kejahatan kerah putuh (white collar crime). Kedua, salah satu sektor yang berkenaan dengan kejahatan korporasi adalah sektor Sumber daya Alam (SDA). Ketiga, bila memperhatikan rumusan pertanggungjawaban pidana korporasi di sektor SDA akan ditemukan pengaturan yang berbeda sehingga menimbulkan ketidakpastian hukum - mempengaruhi penegakan hukum. Keempat, merujuk pada teori-teori pertanggungjawaban pidana maka teori ideal yang dapat diadopsi dalam pertanggungjawaban pidana korporasi di sektor SDA adalah teori strict liability dan direct corporate criminal liability.

Kedua teori ini memungkinkan penuntutan dan pembuktian kesalahan korporasi praktis lebih mudah. Kelima, terkait dengan ius constituendum maka saya mengusulkan agar pembentuk undangundang memperhatikan aspek lain dalam mengatur pertanggungjawaban pidana korporasi di sektor SDA yaitu perihal penggunaan konsep double track system yakni menadopsi sanksi pidana dan tindakan secara bersamaan, reformulasi pada strafsoort dan strafmaat sanksi pidananya, sehingga dapat memberikan efek jera dan mampu memulihkan kerugian yang ditimbulkan.

\section{DAFTAR PUSTAKA}

\section{A. Buku}

Ancel, Marc, 1965, Social Defence, A Modern Approach to Criminal Problems, Routledge \& Kegan Paul, London.

Arief, Barda Nawawi , 2003, Kapita Selekta Hukum Pidana, Citra Aditya Bakti, Bandung , 2008, Bunga Rampai Kebijakan Hukum Pidana: Perkembangan Penyusunan RUU KUHP Baru, Kencana Pernada Media Group, Jakarta.

Atmasasmita, Romli, 2010, Globalisasi dan Kejahatan Bisnis, Kencana Pernada Media Group, Jakarta. ,2010, Perbandingan Hukum Pidana, Mandar Maju, Bandung.

Bederman, David J., 2008, Globalization and International Law, Palgrave Macmilan, New York.

Black, Henry Campbell, 1968, Black's Law Dictionary: Definition of The Term and Phrases of American and English Jurisprudence, Ancient and Modern (Revisied Edition), West Publishing Co, ST
Paul Minn.

Boot, Matcheld, 2001, Nullum Crimen Sine Lege and The Subject Matter Jurisdiction of the International Criminal Court: Genocide, Crimes Against Humanity, War Crimes, Intersentia Antwerpen, New York.

Braithwaite, John, 1994, Corporate Crime in the Pharmaceutical Industry, Routledge and Kegan Paul, London.

Dobson, Paul, 2008, Criminal Law (Eight Edition), Thomson Sweet and Maxwell, London.

Garner, Bryan A., 2011, Black's Law Dictionary (Seventh Edition), West Publishing, ST Paul Minn.

Gelinas, Jacques, 2003, Juggernaut Politics: Understanding Predatory Globalization, Harvard University Press, New York.

Hiariej, Eddy O.S., 2014, Prinsip-Prinsip Hukum Pidana, Cahya Atma Pustaka, Yogyakarta.

Jonkers, E., 1987, Buku Pedoman Hukum Pidana Hindia Belanda, Bina Aksara, Jakarta.

Lavave, Wayne R., 2010, Principle of Criminal Law, West A Thomson Reuters Bussines, 
London.

Mertokusumo, Sudikno dan Pitlo, A., 2013, Bab-

Bab Tentang Penemuan Hukum, Citra Aditya

Bakti, Bandung.

Muladi dan Priyatno, Dwija, 2013, Pertanggungjawaban Pidana Korporasi

(Edisi Revisi), Kencana Pernada Media Group, Jakarta.

Muladi dan R.S, Diah Sulistyani, 2015, Pertenggungjawaban Pidana Korporasi (Corporate Criminal Responsibility), Alumni, Bandung.

Pinto, Amanda dan Evans, Martin, 2003, Corporate Criminal Liability, Sweet and Maxwell, London.

Pound, Roscoe, 1922, An Introduction to The Philosophy of Law, Oxford University Press, London.

Rahardjo, Satjipto, 2006, Ilmu Hukum (Edisi Revisi), Alumni, Bandung.

Reid, Sue Titus, 1995, Criminal Law (Third Edition), Prentice Hall, New Jersey.

Remelink, Jan, 2003, Hukum Pidana: Komentar Atas Pasal-Pasal Terpenting Dalam Kitab Undang-Undang Hukum Pidana Belanda dan Padanannya Dalam Kitab UndangUndang Hukum Pidana Indonesia, Gramedia Pustaka Utama, Jakarta.

Salinger, Lawrence M., 2005, Encyclopedia of White Collar Crime Vol 1 \& II, Sage Publication, London.

Satria, Hariman, 2014, Anatomi Hukum Pidana Khusus, UII Press, Yogyakarta.

Schaffmeister, D., et al., 1995, Hukum Pidana (Diterjemahkan oleh J.E Sahetapy), Liberty, Yogyakarta.

Setiyono, 2005, Kejahatan Korporasi: Analisis Viktimologi dan Pertanggungjawaban Korporasi Dalam Hukum Pidana Indonesia, Bayu Media, Malang.
Sholehuddin, M., 2007, Sistem Sanksi Dalam Hukum Pidana: Ide Dasar Double Track System \& Impelementasinya, Rajawali Press, Jakarta.

Shover, Neal dan Hochstetler, Andy, 2006, Choosing White Collar Crime, Cambridge University Press, New York - Meulborne.

Simpson, Sally S., 2005, Corporate Crime, Law, and Social Control, Cambridge University Press, New York.

Sjadeini, Sutan Remy, 2006, Pertanggungjawaban Pidana Korporasi, Grafiti Pers, Jakarta.

Stone, Jon R., 2005, Dictionary of Latin Quotations: The Illiterati's Guide to Latin Maxims, Mottoes, Proverbs, and Sayings, Routledge Taylor and Francis Group, New York.

\section{B. Artikel Jurnal}

Nigel Dodd dan Bridget Hutter, Geopolitics and The Regulation of Economic Life, Law and Policy Journal Vol. 23, No. 2 Januari 1990.

\section{Internet}

Tax Justice Network, "Financial Secrecy Index", http://www.financialsecrecyindex.com/, diakses 1 Oktober 2015.

Reda Mantovani, "Penuntutan Korporasi dalam Kejahatan Kehutanan", http://www. antikorupsi.org/sites/antikorupsi.org/ files/doc/Reda\%20M_Penuntutan\%20 Korporasi\%20dalam\%20Kejahatan\%20 Kehutanan.pdf, diakses 1 Oktober 2015.

\section{Peraturan Perundang-Undangan}

Undang-Undang Darurat Nomor 7 Tahun 1955 tentang Pengusutan, Penuntutan dan Peradilan Tindak Pidana Ekonomi (Lembaran Negara Republik Indonesia Tahun 1955 Nomor 27, Tambahan Lembaran Negara Republik Indonesia Nomor 801). 